Beech, F. W. \& Carr, J. G. (1955). J. gen. Microbiol. 12, 85-94.

\title{
A Survey of Inhibitory Compounds for the Separation of Yeasts and Bacteria in Apple Juices and Giders
}

\author{
By F. W. BEECH and J. G. CARR \\ Research Station, Long Ashton, Bristol
}

SUMMARY: Selected species of yeasts, lactic acid bacteria and acetic acid bacteria were tested against twenty-six antibiotics and twenty other organic compounds during a search for methods for separating chosen members of the mixed microflora of apple juices. Some of these compounds were found to be specifically inhibitory against either yeasts or lactic acid bacteria, but few inhibited completely such acetic acid bacteria as were tested.

The isolation of yeasts and lactic acid bacteria from apple juices and ciders calls for suitable differential media since the raw materials contain moulds and acetic acid bacteria whose growth must be restricted, otherwise they overgrow the primary isolation plates. In fresh and actively fermenting juices it is also difficult to make an accurate count of the lactic acid bacteria because of the large number of yeasts present, whereas in fully fermented ciders the counting problem is reversed since these lactic acid bacteria then form the major part of the microflora.

In preliminary work it was found that the following measures proved partially successful: $(a)$ the use of apple juice media at $\mathrm{pH} 4.8$ to discourage non-aciduric organisms; $(b)$ anaerobic incubation to encourage the growth of lactic acid bacteria, followed by a further period of aerobic incubation when a yeast count was also required; $(c)$ incorporation of 50 p.p.m. Acti-dione in media when isolating bacteria or 50 p.p.m. aureomycin when yeasts were being examined; $(d)$ use of 100 p.p.m. diphenyl to suppress mould growth.

Certain yeast species resisted Acti-dione, and bacterial colonies occasionally grew in the presence of aureomycin. A search was therefore made for more selective inhibitory compounds which, incorporated in a medium, would permit only the growth of (i) yeasts, (ii) lactic and acetic acid bacteria, (iii) lactic acid bacteria or (iv) individual yeast genera or species of lactic acid bacteria. A simple screening method was used so that a large number of compounds could be tested against a wide range of yeasts and aciduric bacteria chosen from type culture collections. Each compound was tested in a standard malt wort at a number of concentrations to determine at which of these inhibition occurred; the true minimum inhibitory concentration was not determined.

\section{METHODS}

Organisms. The organisms used in these tests are given in Table 1. The yeasts were obtained from the Centraalbureau voor Schimmelcultures, Delft, representing at least one species of seventeen genera of non-pathogenic yeasts. With 
the exception of Candida pulcherrima, all were type strains as given by Lodder \& van $\mathrm{Rij}$ (1952); the strain of C. pulcherrima was that used by van der Walt (1952) in his tests for pigment production.

Both hetero- and homo-fermentative lactic acid bacteria were chosen from the genera Leuconostoc, Streptococcus and Lactobacillus (Bergey's Manual, 1948). In addition, two unidentified Gram-positive heterofermentative bacteria were included (both isolated from cider), one a coccus and the other a rod. Apart from these last two organisms and Acetobacter mobile, all the bacteria were obtained from the National Collection of Industrial Bacteria, Teddington, Middlesex.

Table 1. List of test organisms used

\section{Yeasts}

Family Endomycetaceae

1. Schizosaccharomyces pombe

2. Saccharomyces cerevisiae

3. S. cerevisiae var. ellipsoideus

4. S. pastorianus

5. S. rouxii

6. S. carlsbergensis

7. S. fragilis

8. Pichia membranaefaciens

9. Hansenula anomola

10. Debaryomyces hansenii

11. Saccharomycoides ludwigii

12. Hanseniaspora valbyensis

13. Lipomyces starkeyi

Family Sporobolomycetaceae 14. Bullera alba

Family Cryptococcaceat

15. Cryptococcus laurentii

16. Torulopsis colliculosa

17. Brettanomyces bruxellensis

18. Candida utilis

19. C. mycoderma

20. C. pulcherrima

21. Kloeckera apiculata

22. Trigonopsis variabilis

23. Rhodotorula glutinis
Bacteria

Lactic acid bacteria

Genus Leuconostoc

24. L. mesenteroides

25. L. dextranicum

26. L. citrovorum

27. C. $1^{*}$

Genus Streptococcus

28. S. cremoris

Genus Lactobacillus

Heterofermenters

29. $L$. brevis var. rudensis

30. L. brevis

31. L. fermenti

32. L. pastorianus

33. L. buchneri

34. L. hilgardii

35. V 822 $\uparrow$

Homofermenters

36. L. casei

37. L. plantarum

38. L. leichmanni

Acetobacter spp.

39. A. keutzingianum

40. A. pasteurianum

41. A. aceti

42. $A$. orleanense

43. A. mobile

* Heterofermentative coccus isolated from cider. $\dagger$ Heterofermentative rod isolated from cider.

Medium. The organisms were maintained and tested on a wort medium (pH 5.4) prepared from the same batch of malt by the method of Lodder \& van Rij (1952), but sterilized by intermittent steaming instead of autoclaving. Two liquid worts were prepared, one at sp.gr. 1.060 for subculturing yeasts and the other at sp.gr. 1.040 for bacteria. The solid medium for the actual tests was prepared by adding $2 \%$ agar to wort of sp.gr. $1 \cdot 040$. 
Compounds tested. The compounds used in these tests are listed in Table 2, which also, where necessary, gives the sources from which they were obtained.

Table 2. Compounds tested for possible inhibitory action against the yeasts and bacteria

\begin{tabular}{|c|c|}
\hline \multicolumn{2}{|r|}{ Antibiotics } \\
\hline Compound & Address of supplier \\
\hline \multicolumn{2}{|l|}{ Compound A 18 , } \\
\hline , A 228 & Glaxo Laboratories Ltd., Sefton Park, Stoke Poges, Buckingham- \\
\hline A432 & shire \\
\hline , A 583 & \\
\hline Acti-dione & The Upjohn Co., Kalamazoo, Michigan, U.S.A. \\
\hline Actinomycin & Merck and Co. Ltd., Rahway, New Jersey, U.S.A. \\
\hline Aspergillic acid & Northern Regional Research Laboratory, Peoria 5, Illinois, U.S.A. \\
\hline Aureomycin & Lederle Laboratories Division, Aberdare, Glam., S. Wales \\
\hline Bacitracin & National Institute for Medical Research, Mill Hill, London, N.W. 7 \\
\hline Chloramphenicol & Parke, Davis and Co. Ltd., Hounslow, Middlesex \\
\hline Clavatin & Biochemical Laboratories, Imperial College, London, S.W.7 \\
\hline Frequentin & I.C.I. Ltd., Butterwick Laboratories, Welwyn, Hertfordshire \\
\hline Gliotoxin & Northern Regional Research Laboratory, Peoria 5, Illinois, U.S.A. \\
\hline Kojic acid & Biochemical Laboratories, Imperial College, London, S.W.7 \\
\hline Licheniformin & National Institute for Medical Research, Mill Hill, London, N.W.7 \\
\hline Neomycin & The Upjohn Co., Kalamazoo, Michigan, U.S.A. \\
\hline Nisin & Applin and Barrett Ltd., Yeovil, Somerset \\
\hline Polymyxin B & Burroughs Wellcome and Co., Euston Road, London, N.W.1 \\
\hline $\left.\begin{array}{l}\text { Penicillin G } \\
\text { Streptomycin }\end{array}\right\}$ & Antibiotics Research Station, Clevedon, Somerset \\
\hline Streptothricin & Merck and Co. Inc., Rahway, $\mathrm{Ne}$ \\
\hline Subtilin & National Institute for Medical Research, Mill Hill, London, N.W.7 \\
\hline Terramycin & I.C.I. Ltd., Butterwick Laboratories, Welwyn, Hertfordshire \\
\hline Thiolutin & $\begin{array}{l}\text { Northern Regional Research Laboratory, Peoria 5, Illinois, } \\
\text { U.S.A. }\end{array}$ \\
\hline Tomatine & $\begin{array}{l}\text { Eastern Regional Research Laboratory, Philadelphia 18, Pa., } \\
\text { U.S.A. }\end{array}$ \\
\hline Tyrothricin & Sharp \& Dohme Ltd., Hoddesdon, Hertfordshire \\
\hline
\end{tabular}

Other compounds

$\beta$-Phenylethyl alcohol; Benzoic acid; Methyl- $p$-hydroxybenzoate; Ethyl-phydroxybenzoate; Propyl- $p$-hydroxybenzoate

Dehydroacetic acid; Diphenyl; Ferbam (Ferric dimethyl dithiocarbamate)

Pandurol, J. M. Collet \& Co. Ltd., Bristol Road, Gloucester

Pentachlorophenol; $p$-Nitrophenol; 2:4-Dinitrophenol; o-Phenylphenol; $1: 3-$ Dichloro-2-naphthol

8-Hydroxyquinoline; Salicylanilide; Sorbic acid; Mercaptoacetic acid; Thiourea.

\section{Method of testing for possible inhibitors}

Preparation of inocula. Actively growing cultures $(5 \mathrm{ml}$.$) were centrifuged$ and the organisms resuspended in $\mathbf{0 . 5} \mathrm{ml}$. sterile saline.

Preparation of test plates. Stock solutions of the inhibitory compounds were freshly prepared, water-soluble compounds were dissolved in sterile water without further sterilization; others were dissolved in absolute ethanol, acetone or pyridine. For antibiotics, $1.66 \mathrm{ml}$. of solutions of 5000, 500 and 100 p.p.m. dilutions were added to $15 \mathrm{ml}$. lots of molten $\left(50^{\circ}\right)$ wort agar in $1 \mathrm{oz}$. 
screw-capped bottles to give final concentrations of 500, 50 and 10 p.p.m. respectively. The contents of the bottles were mixed, poured into sterile Petri dishes, allowed to set and dried at $25^{\circ}$ for $2 \mathrm{hr}$. before inoculation. Similarly, $0 \cdot 63,0 \cdot 46,0 \cdot 31$ and $0 \cdot 15 \mathrm{ml}$. of 50,000 p.p.m. solutions of the other inhibitory compounds were used to give final concentrations of 2000,1500, 1000 and 500 p.p.m. Occasionally it was necessary to depart from these methods when using less soluble compounds or where intermediate concentrations in the agar were required. Control plates containing the greatest concentration of solvent used in each test were also prepared.

Inoculation of plates. Three complete sets of plates were prepared for each compound, each set being inoculated with one group of the test organisms, i.e. yeasts, acetic acid bacteria or lactic acid bacteria. Individual plates were placed upon a card marked with a numbered grid which acted as a guide for the inoculation pattern. This ensured that every organism was spotted in its correct position on the appropriate set of plates. A $2 \mathrm{~mm}$. wire loop was used for all inoculations.

Records. All plates were incubated at $25^{\circ}$ aerobically for yeasts and acetic acid bacteria, but for lactic acid bacteria the plates were kept under partial vacuum in a vessel containing pyrogallol and sodium carbonate (Millis, 1951). The sizes of the colonies were estimated visually after 6 and 12 days of incubation; only the later observations are recorded in this paper. When the lowest concentration used for any compound entirely inhibited one or more groups of organisms, tests were repeated at still lower concentrations.

\section{RESULTS}

Since it is not possible to present in detail here the effect of each compound on every organism over the whole range of concentrations tested, a copy of the complete results will be deposited with the Librarian, General Library, British Museum (Natural History), London S.W. 7, for reference purposes.

The compounds are classified under three headings according to their action on the different organisms; all concentrations are given in p.p.m., unless stated otherwise. When combinations of compounds are given it is probable that the effective concentrations of the constituents would be lower in practice since the values quoted relate to their effect when used singly.

\section{Compounds suitable for selective media}

These compounds differentially inhibited one or more groups of the organisms shown in Table 1.

Inhibition of bacteria. All the bacteria tested were inhibited by the following compounds at the stated concentrations while leaving the yeasts unaffected: aureomycin, 500; chloramphenicol, 500; pentachlorophenol, 10; actinomycin, 0.5 plus aureomycin, 50; penicillin G, 500 plus aureomycin, 50; terramycin, 500 plus aureomycin, 50.

Lactobacillus brevis, $L$. brevis var. rudensis and $L$. buchneri were the most resistant species of lactobacilli and were inhibited only at the highest concentrations of aureomycin, chloramphenicol or pentachlorophenol. Actino- 
mycin inhibited the lactobacilli at very low concentrations, but actinomycin and penicillin $\mathrm{G}$ had no effect on the acetic acid bacteria and inhibited both groups of organisms only when combined with 50 p.p.m. of aureomycin. The mixture tyrothricin, 500 plus aureomycin, 50 also inhibited the yeasts Debaryomyces hansenii, Lipomyces starkeyi, Cryptococcus laurentii and Kloeckera apiculata; this mixture is therefore only suitable if these are either absent from the sample or need not be isolated.

Inhibition of yeasts. All the yeasts were inhibited by the following compounds, which did not affect the bacteria: compound A. 228, 500 units/ml.; methyl- $p$-hydroxybenzoate, 1000; ethyl- $p$-hydroxybenzoate, 1000; dehydroacetic acid, 250; Ferbam, 50; Acti-dione, 125 plus gliotoxin, 50; 8-hydroxyquinoline, 250 plus Acti-dione, 10; thiolutin, 250 plus Acti-dione, 10; $p$-nitrophenol, 250.

In general, the film-forming yeasts were very resistant to most of the inhibitory compounds. Saccharomyces cerevisiae var. ellipsoideus was the most resistant of the fermenting yeasts. This property might prove useful as a supplementary test to differentiate it from its less resistant parent species, if other strains of the two yeasts reacted in a similar manner to the test organisms. Lipomyces starkeyi, Kloeckera apiculata and Rhodotorula glutinis were very sensitive to most of the compounds yet, surprisingly, resisted the action of Acti-dione alone.

Acti-dione and gliotoxin had a complementary inhibitory action. The suggested concentration of Acti-dione in this combination may be reduced to 50 p.p.m. when Cryptococcus laurentii is known to be absent from the sample.

Isolation of lactic acid bacteria. The specific isolation of lactic acid bacteria proved most difficult because many compounds which prevented the growth of acetic acid bacteria also inhibited the lactic acid bacteria at the same or lower concentrations. Only sorbic acid at 2000 p.p.m. inhibited the acetic acid bacteria without affecting the lactic acid bacteria. Sorbic acid did not inhibit all the yeasts, and in order to prevent yeast growth completely this compound had to be used in admixture with dehydroacetic acid, 250; or gliotoxin, 500; or Acti-dione, 50. The last mixture may still permit the growth of Brettanomyces bruxellensis and Trigonopsis variabilis, but as these are encountered only infrequently this may be of little consequence.

\section{Compounds of limited value for selective media}

Few raw materials would contain all the yeasts and bacteria used in these tests, so that the compounds in this section may be equally valuable for isolating members of a more limited microflora.

Resistant yeasts. Each of the inhibitory compounds listed below allowed the selective isolation of a restricted number of yeasts which are coded as in Table 1. Bacterial contaminants may, if necessary, be inhibited by the addition of one of the compounds which inhibited all the bacteria tested (see above paragraphs labelled 'Inhibition of bacteria').

In the tabulated records which follow, the data are given in the following 
way: compound, concentration used in p.p.m., code number (from Table 1) of resistant organisms.

Compound A. 228, 500: 7, 8, 9, 18, 19, Clavatin, 500: 3, 22. 22.

Frequentin, 125: 8, 9, 19.

Acti-dione, 500: $7,12,13,17,21,22$,

23.

Frequentin, 250: 19.

Gliotoxin, 500: 8, 9, 11, 19.

Acti-dione, 50 + gliotoxin, 50: 15. Phenol, 2000: 3, 7, 8, 9, 17, 18

Acti-dione, 50 + sorbic acid, 2000: 17, Polymyxin B, 500: 1, 3, 5, 7, 8, 9, 22.

Aspergillic acid, 500 or 8-hydroxyquinoline, 250: 9.

$n$-propyl-p-hydroxy-benzoate, $250: 3$, $7,9,10,15,18$. 22.

Salicylanilide, $1500: 3,4,12,17$.

Sorbic acid, $1000: 2,3,5,6,16,17,18$, 22.

Thiolutin, 250: 8, 19 .

Resistant lactic acid bacteria. The compounds given below allowed the preferential isolation of certain of the lactic acid bacteria (code numbers as in Table 1). Certain of these compounds will also suppress yeasts and acetic acid bacteria present as contaminants. Where they are ineffective in this respect they may be combined with a compound from among those listed above in the paragraph Isolation of lactic acid bacteria.

Aureomycin, $>50$ and $<500: 24,29$, 30, 33.

Benzoic acid, > 2000: 33.

Gliotoxin, 500: 33.

$n$-Propyl- $p$-hydroxy-benzoate, 1000 : $29,30,31,32,33,35,36,38$.

Chloramphenicol, 500: 27, 33, 36, 37.

Clavatin, 500: 29, 30, 33.

Neomycin, > 500: 34, 36, 37.

Pandurol, 10: 29, 30, 31, 32, 33, 35, 38.
2: 4-Dinitrophenol, $100: 29,30,31,32$, $33,34,35,36,37,38$.

o-Phenylphenol, 250: 24, 26, 29 to 35 , $37,38$.

8-Hydroxyquinoline, $2000: 25,29,30$, $36,37$.

Salicylanilide, $>2000: 33,36$.

Streptomycin, 500: 27, 29, 30, 31, 33, 37.

Mercaptoacetic acid, 200: 31, 32, 34, 37.

Thiolutin, >250: 29.

But for the fact that 250 p.p.m. o-phenylphenol inhibited Leuconostoc mesenteroides, C. 1, Streptococcus cremoris and Lactobacillus casei, this compound could have been included among those listed above as useful for the isolation of lactic acid bacteria since it inhibited all the yeasts and acetic acid bacteria at this concentration.

The heterofermentative members of Lactobacillus, e.g. L. buchneri, were more resistant than the homofermentative species to the action of the test compounds. Similarly, the heterofermentative Leuconostoc spp. were less easily suppressed than the homofermentative Streptococcus cremoris, but the resistance of the cocci as a group was less than that of the rods.

\section{Compounds useless for selective media}

The remaining substances tested, namely, compounds A 18 and A 583, bacitracin, kojic acid, licheniformin, nisin, $\beta$-phenylethyl alcohol, streptothricin, subtilin, thiourea and tomatine, were unsuitable for preparing differential media since they were not sufficiently selective in their action even at the highest concentrations used in these tests. 


\section{Compounds suitable for suppressing moulds}

A number of the compounds tested are normally used as fungicides, but of these only diphenyl was found suitable for incorporation in media for the suppression of mould contaminants. When used at 2000 p.p.m. the lactic acid and acetic acid bacteria were unaffected, and the only yeasts inhibited were Debaryomyces hansenii, Bullera alba, Cryptococcus laurentii, Kloeckera apiculata and Rhodotorula glutinis. In routine practice diphenyl was used at 100 p.p.m. and all the yeasts grew satisfactorily at this concentration while mould contaminants were suppressed.

\section{Effect of solvents}

Of the inhibitory compounds tested twenty-five were soluble in water, eighteen in ethanol, two in dilute pyridine water and one in acetone. The effects of these solvents on the test organisms were as follows.

Yeasts. The control plates contained $10 \%(\mathrm{v} / \mathrm{v})$ ethanol, the highest concentration used in the actual tests. When the experiments were begun it was found that seven of the yeasts (Debaryomyces hansenii, Hanseniaspora valbyensis, Lipomyces starkeyi, Bullera alba, Cryptococcus laurentii, Kloeckera apiculata and Rhodotorula glutinis) sometimes failed to grow or the colonies were much decreased in size compared with those on the normal control plates. This was largely overcome by using inocula not more than 3 days old, preparing fresh media every 14 days and standardizing the period of plate-drying before inoculation. Under these conditions only the ethanol sensitive yeasts, Bullera alba, Kloeckera apiculata and Rhodotorula glutinis failed to develop fully. For these organisms no results are recorded in cases when it was found that a particular concentration of ethanol was reinforcing the inhibitory effect of a given compound.

The initial rate of growth of the other yeasts was slightly delayed by ethanol, but after 12 days incubation, the colonies were the same size as those on the normal control plates. Similar results were obtained with acetone and pyridine water.

Bacteria. The lactic acid bacteria were not affected by any of the four solvents, while the growth of the acetic acid bacteria was slightly retarded on the ethanol control plates during the early stages of incubation.

\section{DISCUSSION}

These results show that some of the compounds tested are suitable for the selective isolation of yeasts and lactic acid bacteria from mixed microfloras such as are found in apple juices and ciders. Similar differential isolation techniques have been used in other fermentation industries, although a smaller number of inhibitory compounds have been tested (Strandskov, Brescia \& Bockelmann, 1953; Gray \& Kazin, 1946). One of the main experimental uses of antibiotics in such instances has been the suppression of undesirable organisms in several fermentation products (Day, Serjak, Stratton \& Stone, 1954; Strandskov \& Bockelmann, 1953; Strandskov, Baker \& Bockelmann, 
1953). Much smaller amounts of inhibitory compounds were required to suppress such species under these conditions than were needed in pure culture methods, no doubt because of the lack of competition for nutrients in the latter. A wide range of compounds was tested by Fitzgerald \& Jordan (1953) for the suppression of pure cultures of oral lactobacilli; the inhibitory levels quoted agree closely with those presented here. The compounds of the greatest interest in the present tests are summarized below.

Acti-dione. Whiffen (1948) found that this substance had no effect on bacteria but inhibited many, although not all, yeast genera. Similar results were obtained in the present tests and in the routine plating of apple juice samples on media containing Acti-dione. Acti-dione has been used for counting bacterial contaminants in brewery yeasts and beers (Phillips \& Hanel, 1950; Green \& Gray, 1951; Strandskov \& Bockelmann, 1951); it was found ideal for this purpose because brewery yeasts are especially sensitive to it.

Actinomycin was the most effective inhibitor for the lactic acid bacteria; according to Reilly, Schatz \& Waksman (1945) it is also fungistatic.

Aureomycin was valuable for inhibiting bacterial growth, especially acetic acid bacteria; it had no effect on yeast growth at 500 p.p.m. (Hesseltine, Hauck, Hagen \& Bohonos, 1952). Terramycin, which has a similar chemical constitution, was less effective.

Chloramphenicol, often used to inhibit Gram-negative bacteria, did not suppress the acetic acid bacteria differentially.

Dehydroacetic acid was a good yeast inhibitor at 250 p.p.m. without affecting bacterial growth. It is only fungicidal at higher concentrations (Eeckhaut, 1952; Mossel \& de Bruin, 1950; Wolf, 1950).

Diphenyl has been used for several years at Long Ashton to prevent mould growth (Hertz \& Levine, 1942). At 100 p.p.m. it does not affect yeast or bacterial growth, in contrast with many other fungicides which suppress these organisms at fungistatic concentrations.

Frequentin was found to be an effective yeast inhibitor; its use for this purpose has not been previously reported. It is also fungicidal (Curtis, Hemming \& Smith, 1951).

Gliotoxin inhibited most of the test yeasts at 500 p.p.m. but was not as selective as frequentin since it was also anti-bacterial at this level.

8-Hydroxyquinoline was a most effective yeast inhibitor at concentrations which left the test bacteria unaffected. Previous reports have concerned its effect on fungi and bacteria (Albert, 1953).

Sorbic acid was the only compound that inhibited the acetic acid bacteria but not the lactobacilli (Emard \& Vaughn, 1952). It also inhibited many of the test yeasts. Phillips \& Mundt (1950) used this compound to inhibit film yeasts in pickle brines to allow the preferential growth of species of Leuconostoc and Lactobacillus.

We wish to thank Prof. K. E. Cooper, Dr Lilian E. Hawker and Dr A. Pollard of the University of Bristol for very helpful advice. We should also like to thank Miss Jeanne H. Baker and Miss Janet M. Lovell for their technical assistance. We are 
indebted to Dr C. Rainbow, University of Birmingham, for a culture of Acetobacter mobile and for gifts of antibioties and inhibitory compounds to: Drs R. G. Benedict, P. W. Brian, H. W. Buston, T. D. Fontaine, H. B. Hawley, K. A. Lees, J. W. Lightbown, H. B. Woodruff, Messrs R. C. Codner, S. H. Crowdy, W. Klomparens, Messrs Burroughs Wellcome and Co., J. M. Collett and Co. Ltd., Cyanamid Products Ltd., and Sharp and Dohme Ltd.

\section{REFERENCES}

Albert, A. (1953). Mode of action of antibacterial substances. Symposium Growth Inhibition and Chemotherapy. Oxford: Blackwell.

Bergey's Manual of Determinative Bacteriology (1948). Ed. R. S. Breed, E. G. D. Murray \& A. P. Hitchens, 6th ed. London: Baillière, Tindall and Cox.

Curtis, P. J., Hemming, H. G. \& Smith, W. K. (1951). Frequentin: an antibiotic produced by some strains of Penicillium frequentans Westling. Nature, Lond. 167, 1951.

Day, W. H., Seruak, W. C., Stratton, J. R. \& Stone, L. (1954). Antibiotics as contamination control agents in grain alcohol fermentations. J. agric. Food Chem. $2,252$.

Eeckнaut, R. G. (1952). Dehydroacetic acid, a new antiseptic. Fermentatio, p. 123,

Emard, L. O. \& Vaughn, R. H. (1952). Selectivity of sorbic acid media for the catalase negative lactic acid bacteria. $J$. Bact. 63,487 .

Fitzgerald, R. J. \& Jordan, H. V. (1953). The in vitro effects of antibiotics and other inhibitory agents on representative oral Lactobacilli. Antibiot. \& Chemotherap. 3, 231.

Gray, P. P. \& Kazin, A. D. (1946). Antibiotics and the treatment of brewer's yeast. Wallerstein Labs. Commun. 9, 115.

Green, S. R. \& Gray, P. P. (1951). A differential procedure for bacteriological studies useful in the fermentation industries. Wallerstein Labs. Commun. 14, 289.

Hertz, M. R. \& Levine, M. (1942). A fungistatic medium for enumeration of yeasts. Food Res. 7, 430.

Hesseltine, C. W., Hauck, M., Hagen, M. T. \& Bohonos, N. (1952). Isolation and growth of yeasts in the presence of aureomycin. J. Bact. 64, 55.

Lodder, J. \& Kreger-van RiJ, N. J. W. (1952). The Yeasts. Amsterdam: NorthHolland Publ. Co.

Mrlus, N. F. (1951). Some bacterial fermentations of cider. Ph.D. Thesis : University of Bristol.

Mossel, D. A. A. \& De Bruin, A. S. (1950). A preliminary report on the antimicrobic properties of dehydroacetic acid. Leeuwenhoek ned. Tijdschr. 16, 393.

Phillips, G. B. \& Hanel, Jun., E. (1950). Control of mould contaminants on solid media by the use of actidione. J. Bact. 60, 104.

Phillips, G. F. \& Mundt, J. O. (1950). Sorbic acid as inhibitor of scum yeasts in cucumber fermentations. Food Tech. 4, 291.

Reilly, H. C., Schatz, A. \& Waksman, S. A. (1945). Antifungal properties of antibiotic substances. J. Bact. 49, 585.

Strandskov, F. B. \& Bockelmann, J. B. (1951). New method for counting the bacterial contaminants of brewer's yeast. J. Inst. Brewing, 57, 123.

Strandskov, F. B. \& Bockelmann, J. B. (1953). Antibiotics as inhibitors of microbiological contamination in beer. J. agric. Food Chem. 1, 1219.

Strandskov, F. B., Baker, H. W. \& Bockelmann, J. B. (1953). A study of the gram-negative bacterial rod infection of brewery yeast and brewery fermentations. Wallerstein Labs. Commun. 16, 261. 
Strandskov, F. B., Brescia, J. A. \& Bockelmann, J. B. (1953). The application of selective bacteriostasis to brewery bacteriology. Wallerstein Labs. Commun. 16, 31.

vaN Der Walt, J. P. (1952). On the yeast Candida pulcherrima and its pigment. Doctorial Thesis: Delft.

WhIFFEN, A. J. (1948). The production, assay and antibiotic activity of actidione, an antibiotic of Streptomyces griseus. J. Bact. 56, 283.

Wolf, P. A. (1950). Dehydroacetic acid. A new microbiological inhibitor. Food' Tech. 4, 294.

(Received 11 August 1954) 